\title{
EFFECT OF PESTICIDES ON NITRIFICATION IN AQUATIC SEDIMENT
}

\author{
ENRICH-PRAST, A. \\ Departamento de Ecologia, Instituto de Biologia, Universidade Federal do Rio de Janeiro, \\ CCS, Cidade Universitária, C. P. 68020, CEP 21941-590, Rio de Janeiro, RJ, Brazil \\ Correspondence to: Alex Enrich-Prast, Departamento de Ecologia, Instituto de Biologia, \\ Universidade Federal do Rio de Janeiro, CCS, Cidade Universitária, C. P. 68020, CEP 21941-590, \\ Rio de Janeiro, RJ, Brazil, e-mail: aeprast@biologia.ufrj.br \\ Received February 12, 2004 - Accepted July 1, 2004 - Distributed May 31, 2006
}

(With 3 figures)

\begin{abstract}
The aim of this work was to study the effect of the herbicides glyphosate, nonanoic acid, and dichlorprop-P and the insecticides potassium oil, malation and Pyretrin and their combinations on nitrification. Nitrification was measured in slurries from the eutrophic and shallow Brabrand Lake (Aarhus, Denmark), by inhibiting oxidation of nitrite to nitrate with chloride. All herbicides and insecticides influenced nitrification. The No Observed Effect Concentration (NOEC) was assessed to be $30 \mu \mathrm{g} . \mathrm{L}^{-1}$ for glyphosate and nonanoic acid and $1 \mu \mathrm{g} . \mathrm{L}^{-1}$ for dichlorprop-P. The NOEC for malation and Pyretrin on nitrification was assessed to be $3 \mu \mathrm{g} . \mathrm{L}^{-1}$. No accumulation effect on nitrification of the insecticides malation and Pyretrin, or of the studied herbicides, was observed, indicating that their environmental impact is low at reduced concentrations, even in combination. The procedure used in this study can provide a useful tool for obtaining concentration limits for pesticides or other chemicals in a short period of time.
\end{abstract}

Keywords: nitrification, pesticides, sediment.

\section{RESUMO}

\section{Efeito de pesticidas sobre nitrificação em sedimento de ecossistemas aquáticos}

O objetivo desta pesquisa foi avaliar o efeito dos herbicidas "Glyphosate", Ácido Nonânico e "DichlorpropP" e dos insecticidas "Potassium oil", "Malation" e "Pyretrin" e da combinação destes compostos sobre o processo de nitrificação. As taxas de nitrificação foram mensuradas em uma mistura de água e sedimento do lago Brabrand, um lago raso e eutrófico (Aarhus, Dinamarca), por meio da inibição da oxidação do nitrito a nitrato por cloreto. Foi observada uma influência negativa de todos os herbicidas e inseticidas sobre o processo de nitrificação. A Concentração Sem Efeito Observado (CSEO) foi de $30 \mu \mathrm{g} . \mathrm{L}^{-1}$ para Glyphosate e Ácido Nonânico e $1 \mu \mathrm{g} . \mathrm{L}^{-1}$ para Dichlorprop-P. A CSEO para Malation e Pyretrin foi $3 \mu \mathrm{g} . \mathrm{L}^{-1}$. Não foi observado um efeito conjunto dos inseticidas Malation e Pyrethin e de todos os três herbicidas estudados, indicando que o impacto ambiental é baixo quando reduzidas concentrações destas substâncias estão presentes ao mesmo tempo no ambiente. O procedimento utilizado nesta pesquisa pode ser uma ferramenta útil para obtenção de limites nas concentrações de pesticidas ou outros produtos químicos em um curto período de tempo.

Palavras-chave: nitrificação, pesticidas, sedimento. 


\section{INTRODUCTION}

In agricultural fields and farms considerable amounts of pesticides are used to increase crop production. Pesticides are borne by soil water to reservoirs and can disturb the natural ecological balance by producing toxic effects in recipient environments. Microbial processes are important for mineral and organic matter cycling in ecological systems, with the nitrogen cycle being crucial for all organisms (Hansson et al., 1991; Tu, 1996). The nitrogen cycle in soil and sediment includes several microbial processes, of which biological nitrogen fixation, denitrification, and nitrification are the most studied processes (Wonk, 1991).

Nitrification is a chemoautotrophic process carried out by two bacterial groups that oxidize ammonium to nitrite and nitrite to nitrate (Fenchel et al., 1998). This process is important to the nitrate content in soil, which is the major source of nitrogen assimilated by higher plants and, thus, of considerable ecological and agricultural importance (Hansson et al., 1991; Tu, 1996). Nitrification in particular has been shown to be very sensitive to chemicals, and nitrifier activity is, therefore, often used as an indicator of chemical disturbances, such as those produced by pesticides (Pell et al., 1998).

Pesticide effects on nitrification can directly influence some processes such as denitrification, which is critical because it lowers eutrophication of freshwater lakes as it removes inorganic nitrogen. As denitrification depends upon nitrate being formed by nitrifiers, nitrification inhibition has a negative impact on the denitrification process and, consequently, on ecosystem equilibrium (Fenchel et al., 1998). Some pesticides have been found to reduce the nitrifying bacterial population. Even if this is only a short-term effect ( 2 weeks), it can be assumed that some pesticides have an impact on bacterial populations and structures and, thus, on soil micro-biodiversity (Tu, 1991).

Studies performed on different soils show varied effects of different pesticides on nitrification. Negative effects such as nitrification reduction or inhibition (Tu, 1991; 1994; Vink \& Van Straalen, 1999), or no inhibitory effects at all (Tu, 1995) have been observed. An increase in nitrification properties have also been demonstrated (Rangaswamy \& Venkateswarlu, 1993; Das, 1997). Furthermore, both positive and negative effects on overall metabolic activity have been found for different concentrations of a single pesticide (Laursen \& Carton, 1999). The aim of this study was to evaluate the effect of six pesticides (three herbicides and three insecticides) on sediment nitrification and to evaluate their combined effect on this process.

\section{MATERIAL AND METHODS}

The sediment used was collected in November 1999 from the eutrophic and shallow Brabrand Lake (Århus, Denmark) into which two small streams flow, carrying wastewater from treatment plants and surrounding agricultural fields and gardens. This 150 ha lake has a primary production of approximately $600 \mathrm{~g} \mathrm{C} \mathrm{m}^{-2} \mathrm{Yr}^{-1}$ (Brix, 1998) and also receives water from the Århus River, which is surrounded by agricultural fields. Water temperature was $6.5^{\circ} \mathrm{C}$ when sediment was collected in Plexiglas tubes at a $1.5 \mathrm{~m}$ depth, and the upper $1-2 \mathrm{~cm}$ of the sediment was transferred to an Erlenmeyer flask. A total of about $1.2 \mathrm{~L}$ of sediment was collected. Prior to the experiments, the sediment was thoroughly homogenized, stored in 30 jars shaded and aerated at room temperature $\left(25^{\circ} \mathrm{C}\right)$ for one week. Sediment porosity was $0.90 \mathrm{~mL} . \mathrm{cm}^{-3}$. The herbicides used were: glyphosate, nonanoic acid and dichlorprop$\mathrm{P}$; the insecticides were: potassium oil, malation and Pyretrin. These six pesticides are commonly used in agriculture and were bought in an ordinary Danish farmers' shop.

Herbicides characteristics: Glyphosate is transported through plants, inhibits the synthesis of amino acids for growth, and is almost nontoxic to mammals and humans. Ninety percent of glyphosate is degraded within 3 months. Investigations show that glyphosate appears to be active only in green parts of plant, and the roots are presumed to be unable to absorb it. Nonanoic acid can be used as a carbon source by microorganisms, followed by complete degradation in the soil within 2 days. Dichlorprop-P is poisonous and carcinogenic to humans.

Insecticides characteristics: Potassium oil, a fatty acid that can be used as a herbicide or an algaecide, is commonly known as a "green" insecticide usable in ecological farming. Malation is one of the safest insecticides with a high selectivity towards insects, and pyretrin is a natural compound occurring in flowers of the genus Chrysanthemum. 
While essentially non-toxic to mammals, it is very fast-acting towards insects.

In this study, nitrification was measured by the method proposed by Belser \& May (1980), in which oxidation of $\mathrm{NO}_{2}^{-}$to $\mathrm{NO}_{3}^{-}$is inhibited by $\mathrm{ClO}_{3}^{-}$. Therefore, measurements in this experiment were potential and cannot be considered the actual nitrification rates in Brabrand Lake. Two $\mathrm{mL}$ of sediment were homogenized and put into 15 falcon tubes $(50 \mathrm{~mL})$, one for each formulated pesticide concentration and one control, followed by addition of $30 \mathrm{~mL}$ aerated Milli-Q water. One $\mathrm{mL}$ of $4 \mathrm{mM} \mathrm{KH}_{2} \mathrm{PO}_{4}$ and $1 \mathrm{~mL}$ of $20 \mathrm{mM} \mathrm{NH}_{4} \mathrm{Cl}$ were added as $\mathrm{P}$ and $\mathrm{N}$ sources, besides $1 \mathrm{~mL}$ of $75 \mathrm{mM}$ $\mathrm{NaClO}_{3}$ to stop oxidation of $\mathrm{NO}_{2}^{-}$to $\mathrm{NO}_{3}^{-}$. To each centrifuge tube $1 \mathrm{~mL}$ of each pesticide was added, reaching final concentrations of $300,100,30,10$, $3,1,0.3,0.1,0.03,0.01,0.003,0.001,0.0003$, and $0.0001 \mu \mathrm{g} . \mathrm{L}^{-1}$ with respect to the active ingredient. After pesticide addition, aerated Milli-Q water was added until a final volume of $40 \mathrm{~mL}$, following which the mixture was incubated on a shaker tray.

Subsamples of $3 \mathrm{~mL}$ were withdrawn four times every $30 \mathrm{~min}$, for a four-time total. These were transferred to $10 \mathrm{~mL}$ centrifuge tubes containing $50 \mu \mathrm{L}$ zinc acetate $(25 \% \mathrm{w} / \mathrm{v})$ to stop bacterial activity, and centrifuged at $5000 \mathrm{rpm}$ for $5 \mathrm{~min}$. One $\mathrm{mL}$ of the supernatant was transferred with a pipette to Eppendorf tubes and stored for later determination of $\mathrm{NO}_{2}^{-}$concentration (Golterman et al., 1978). To the $1.0 \mathrm{~mL}$ supernatant were added $20 \mu \mathrm{L}$ sulphanilamid and $20 \mu \mathrm{L} \mathrm{N}$-1-naphtyl. The mixture was transferred to a microwellplate (A/S Nunc, Denmark) and the absorption measured at $540 \mathrm{~nm}$ (Biotek reader, model El 309). A standard curve was obtained in the range of $1-50 \mu \mathrm{M}$. Potential nitrification rates were calculated as:

Pot. nitrif $=\alpha \frac{\text { Volume of water }}{\text { Volume of sediment }}$

where:

Pot. nitrif. $=$ potential nitrification $\left(\mathrm{nmol} . \mathrm{cm}^{-3} \cdot \mathrm{h}^{-1}\right)$; $\alpha=$ slope of linear regression of accumulated $\mathrm{NO}_{2}{ }_{2}$ in nmol. $\mathrm{L}^{-1} v s$. time in hours $\left(\mathrm{nmol} . \mathrm{L}^{-1} \cdot \mathrm{h}^{-1}\right)$; volume of water in liters $(\mathrm{L})$; and volume of sediment in cubic centimeters $\left(\mathrm{cm}^{-3}\right)$

The potential nitrification rates were plotted against the different herbicide or insecticide concentrations and the regression coefficient values were compared with a $t$ - test $(\mathrm{p}<0.05)$. As some concentrations affect the nitrification rates significantly, the value just before the lowest that significantly affected this process was chosen to trigger an interactive effect between the pesticides. This concentration was called the No Observed Effect Concentration (NOEC).

The interactive effects between the herbicides and insecticides were investigated by combining the three herbicides and the three insecticides at the highest concentrations that in the previous experiments had shown no effect on nitrification, as registered by the NOEC concentration. Every possible combination of the three herbicides and insecticides was tested with three replicates for each combination; they were also tested alone to standardize the results. For testing the significance of each herbicide and insecticide combination an independent $t$-test was performed by SPSS 8.0 for Windows.

\section{RESULTS}

At some concentration all herbicides and insecticides influenced nitrification (Figs. 1 and 2). Except for the insecticide potassium oil, the concentrations were observed to remain constant up to a certain value, whose decrease indicated nitrification activity inhibition. In addition, complete nitrification inhibition was found at high concentrations of the herbicide dichlorprop-P and the insecticides malation and Pyretrin (Figs. 1 and 2). The nitrification rate without any pesticide addition in the first experiment was $145,2 \pm 6,5 \mathrm{nmol} \cdot \mathrm{cm}^{-3} \cdot \mathrm{h}^{-1}($ mean $\pm \mathrm{SD} ; \mathrm{n}=4)$.

For the herbicides, NOEC was assessed to be $30 \mu \mathrm{g} . \mathrm{L}^{-1}$ for glyphosate and nonanoic acid and $1 \mu \mathrm{g} . \mathrm{L}^{-1}$ for dichlorprop-P (Fig. 1). Dichlorprop-P was the most toxic pesticide as the NOEC was the lowest, with nitrification completely inhibited at concentrations higher than $30 \mu \mathrm{g} . \mathrm{L}^{-1}$. The NOEC for malation and Pyretrin on nitrification was assessed to be $3 \mu \mathrm{g}$.L ${ }^{-1}$ (Fig. 2). The herbicide potassium oil presented no clear pattern with many significant variations between the different concentrations. The lowest nitrification rates were measured at concentrations of 0.001 and $0.003 \mu \mathrm{g} . \mathrm{L}^{-1}$ (Fig. 2). As there was no clear potassium oil effect on nitrification (Fig. 2), the NOEC value was assessed to be $300 \mu \mathrm{g} . \mathrm{L}^{-1}$ for the experiment testing combined insecticide influence on nitrification. 

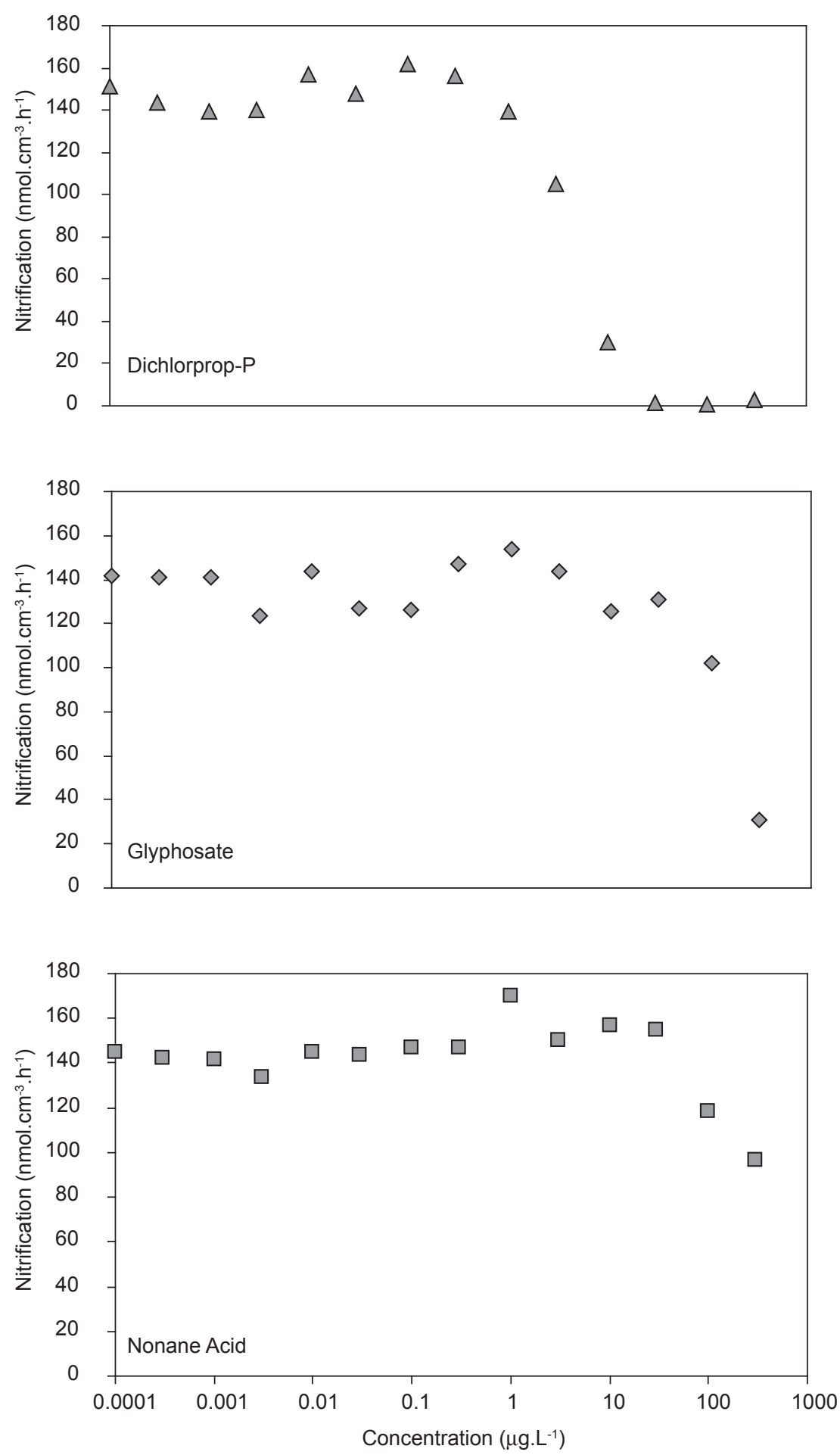

Fig. 1 - Effect of different concentrations of the insecticides potassium oil, malation, and Pyretrin on nitrification rates. These rates without addition of insecticides were 145,2 $\pm 6,5 \mathrm{nmol} \cdot \mathrm{cm}^{-3} \cdot \mathrm{h}^{-1}($ mean $\pm \mathrm{SD} ; \mathrm{n}=4)$. 

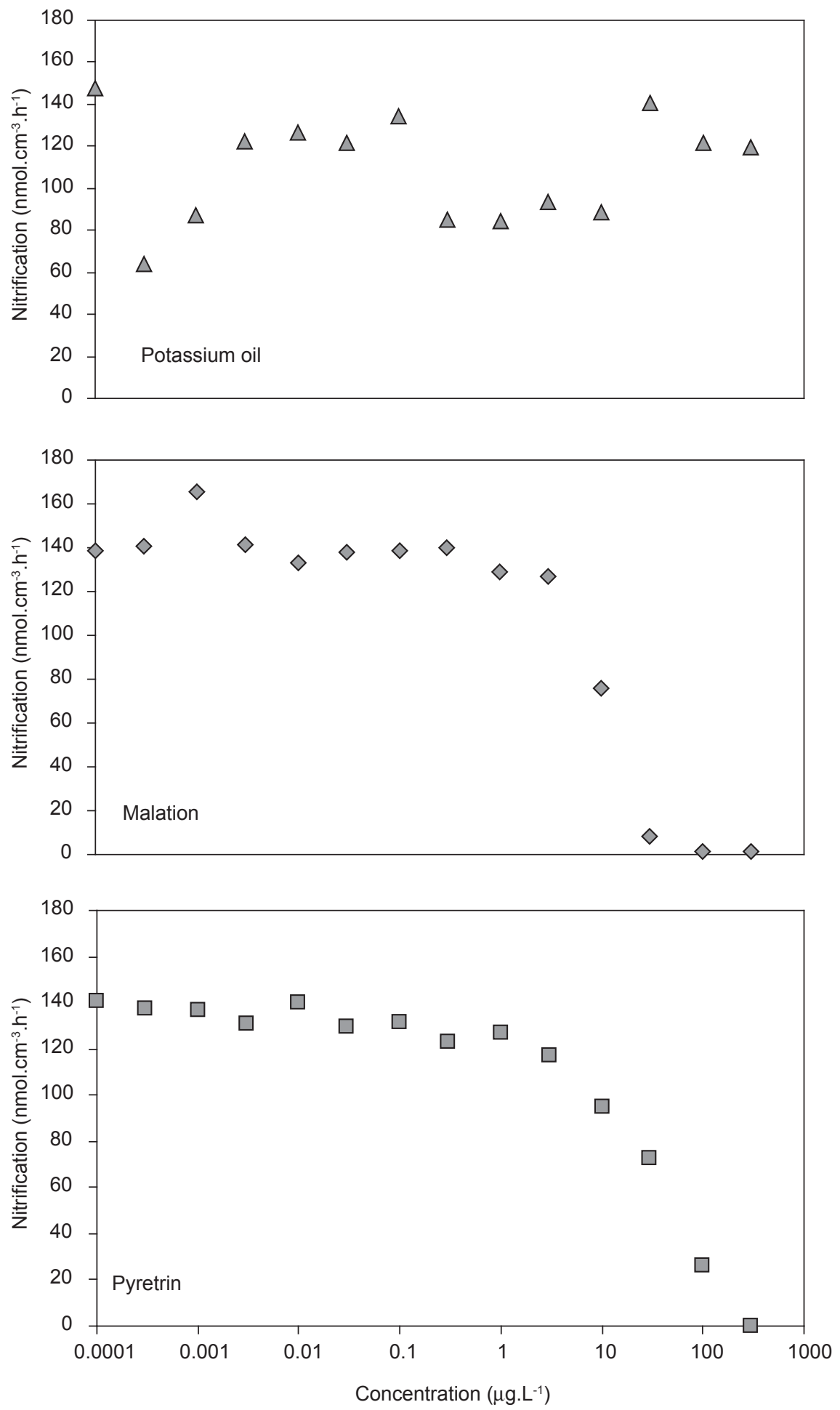

Fig. 2 - Effect of different concentrations of the herbicides dichorprop-P, glyphosate, and nonanoic acid on nitrification rates. These rates without addition of herbicides were $145,2 \pm 6,5 \mathrm{nmol} \cdot \mathrm{cm}^{-3} \cdot \mathrm{h}^{-1}($ mean $\pm \mathrm{SD} ; \mathrm{n}=4)$. 
The herbicide experiment showed that the nitrification rate in the control treatment was significantly higher ( $t$-test, $\mathrm{p}<0.05$; Fig. 3 ) than in all other treatments, i.e., single herbicides or all in combination. The combined insecticides experiment (Fig. 3) showed that the malation and potassium oil combination chosen had a significant inhibitory effect ( $t$-test, $p<0.05 ;$ Fig. 3 ) on nitrification, but not that of the Pyretrin concentration chosen (t-test, $p<0.05$; Fig. 3 ). The malation and Pyretrin combination did not affect nitrification significantly (t-test, $\mathrm{p}<0.05$; Fig. 3 ). The addition of potassium oil when combined with malation or Pyretrin always significantly inhibited nitrification (t-test, $\mathrm{p}<0.05$; Fig. 3). Addition of the three insecticides or herbicides together did not differ significantly (t-test, $\mathrm{p}<0.05$; Fig. 3) from addition of only two combinations (Fig. 3). Nitrification was never completely inhibited at the NOEC used in the combination experiments.
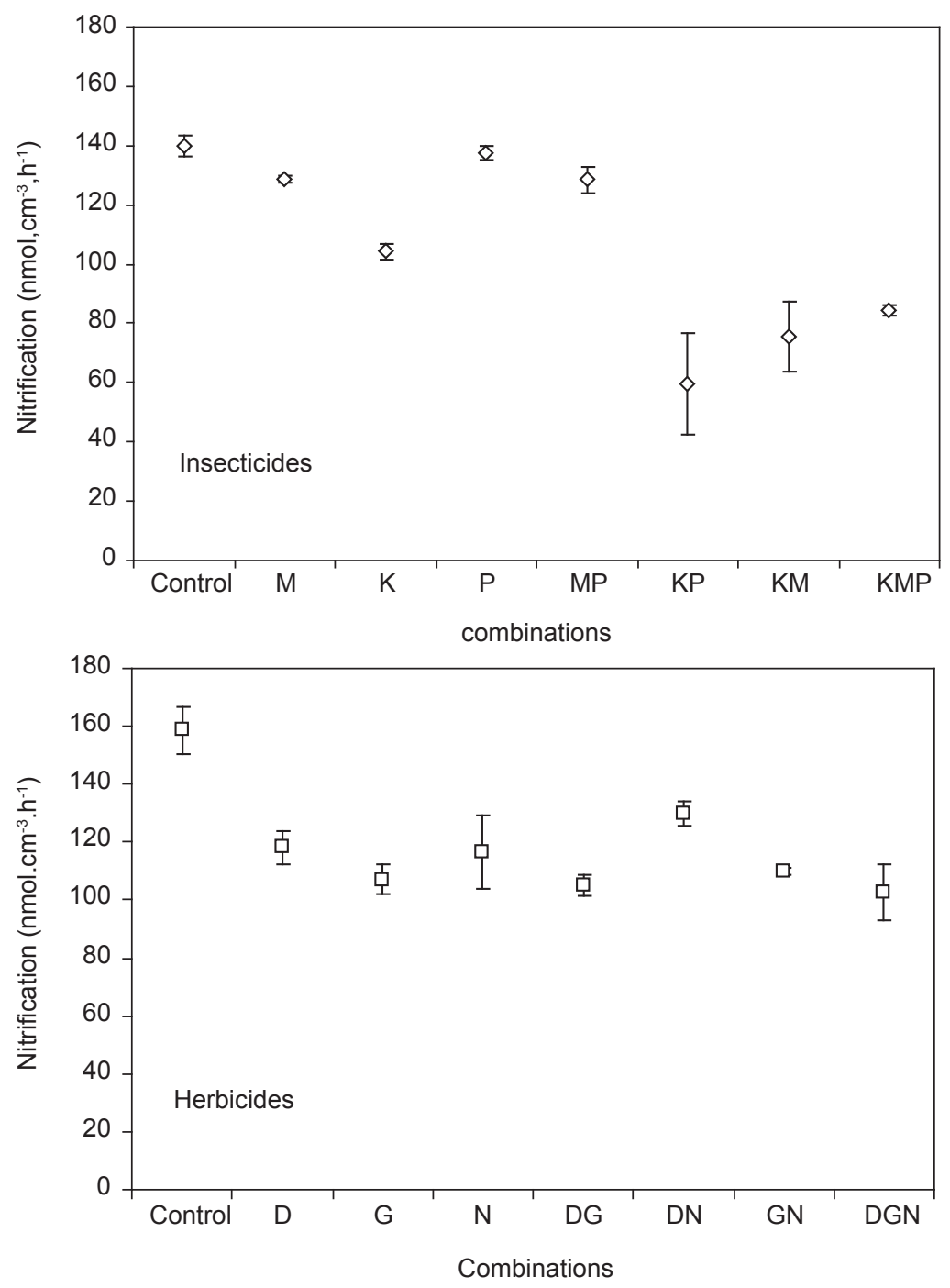

Fig. 3 - Effect of the combination of insecticides or herbicides on nitrification rates. Insecticides were added at the following critical concentrations: malation (M) $-3 \mu \mathrm{g} . \mathrm{L}^{-1}$; potassium oil $(\mathrm{K})-300 \mu \mathrm{g} . \mathrm{L}^{-1}$; and Pyretrin (P) - $3 \mu \mathrm{g} . \mathrm{L}^{-1}$. Herbicides were added at the following concentrations: dichlorprop-P (D) - $1 \mu \mathrm{g} . \mathrm{L}^{-1}$; glyphosate $(\mathrm{G})-30 \mu \mathrm{g} . \mathrm{L}^{-1}$ and nonanoic acid (N) - $30 \mu \mathrm{g} . \mathrm{L}^{-1}$. (n=3; mean \pm 1 S.E. $)$ 


\section{DISCUSSION}

The experiments clearly show that all insecticides and herbicides tested affect the nitrification process negatively at high concentrations. Many researchers have found similar results (i.e., Tu, 1991; Vink \& Van Straalen, 1999; Chen \& Edwards, 2001; Chen et al., 2001). The herbicide dichlorprop$\mathrm{P}$ demonstrated the greatest nitrification inhibition, with complete inhibition at high concentrations. This greater effect of dichlorprop-P on the nitrification rate could be a result of the formulated herbicide Toxan Plænerens, which contains three active ingredients. Dilution was made according to the concentration of the herbicide dichlorprop-P, but Toxan Plænerens also contains the compounds MCPA and DICAMBA, the former at a concentration three times higher than that of the concentration of dichlorprop-P. The nitrification rate may be affected not only by the active ingredient, but also by application solvents and other additives in the formulated preparations. Additive number and properties in the formulated herbicides investigated were not stated, so that the influence of these compounds could not be estimated. However, the nitrification effects of such additives have been tested in several studies. Miller et al. (1996) report that chlorinated solvents inhibit nitrification, and Hansson et al. (1991) have shown that the organic solvents methanol, acetone, and xylol negatively influence nitrification, even at low doses. In order to determine if the active ingredient alone produces the effect on nitrification, it would be necessary to repeat the analysis, using the compound in the pure form. This procedure would depend on manufacturers' consent and willingness to provide the pure compound.

The herbicides glyphosate and nonanoic acid and the insecticides malation and Pyretrin showed less nitrification inhibition at high herbicide concentration than dichlorprop-P. The two herbicides and insecticides showed somewhat similar effects; thus, they presumably had the same NOEC. Potassium oil did not present a clear pattern, so it was difficult to assess a limit indicating the influence of this insecticide on nitrification. As all experiments were performed simultaneously with the same sediment and reagents, it is not likely that the results obtained for potassium oil could be attributed to methodological mistakes. Furthermore, different effects of different pesticide concentrations on ecological processes have also been previously observed (Pell et al., 1998; Laursen \& Carlton, 1999; Chen et al., 2001).

The effect of the herbicide and insecticide combination on nitrification was different. The NOEC values chosen for the insecticides malation and Pyretrin seem to be correct, since the nitrification values did not decrease in comparison to the control. Even the combination of both insecticides did not influence nitrification. The influence on nitrification of potassium oil alone or in combination with the other two insecticides indicates that the NOEC value chosen for potassium oil was higher than it should have been. This clearly indicates that more experiments are necessary to correctly evaluate the toxic effect of potassium oil on nitrification. The NOEC values for all herbicides should be lower, as they negatively influenced nitrification alone or in combination. However, their combined effect was not higher than the influence of any one of them on nitrification, indicating that their effect is not cumulative. Chen \& Edwards (2001) also observed no cumulative effect of 2 different fungicides on nitrification.

The absence of an accumulation effect of the insecticides malation and Pyrethin and all used herbicides on nitrification rates is a very significant finding, specially for regulatory agencies, as these compounds are used in the same environments.

Establishing acceptable levels of the studied pesticides in the environment would certainly require evaluating their effects not only on nitrification, but also on other ecological processes, and also on their accumulation in the food chain (Fraser et al., 2002; Lopez, 2003). While a part of the herbicides applied to soils ends up in streams and lakes, it is important to compare the results from this experiment with the actual values found in nature. The herbicides dichlorprop-P and glyphosate have been detected in several Danish streams and lakes, dichlorprop$\mathrm{P}$ having been found at concentrations varying from 0.01 to $0.3 \mu \mathrm{g} . \mathrm{L}^{-1}$ in nearly $30 \%$ of studied lakes, while glyphosate was found in all studied streams, at concentrations that varied from 0.02 to $0.23 \mu \mathrm{g} . \mathrm{L}^{-1}$ (Bichel-Committee, 1999). As the detected concentrations are lower than the NOEC values estimated in this study, actual impact on nitrification at the various locations listed may be negligible. 
Concentrations of other pesticides in the environment should also be studied and subsequently compared to the NOEC values found. Some insecticides probably do not have a strong environmental influence, e.g., malation, which is one of the safest insecticides due to its high selectivity towards insects. In addition, after application on soil the time required to decompose $75-100 \%$ of the original amount is one week. Therefore, malation's tendency to accumulate in the environment is low (Matsumura, 1985).

Because nitrifiers are particularly sensitive to chemicals (Hanson et al., 1991; Pell et al., 1998), the procedure used in this study is a fast and easy way to evaluate environmental effects of toxic compounds. Furthermore, potential nitrification measurements require no expensive equipment. All the data for obtaining NOEC values were obtained in a 12-h period, which was the same required to perform the combination experiments. When obtaining quick results is a necessity, this procedure could be very useful in establishing application limits for pesticides or other chemicals.

Acknowledgments - I would like to acknowledge the students from the Institute of Biology from the University of Aarhus Birthe Thordahl Christensen, Bjørn Howe Jessen, Dorthe Groth Petersen, Gilles filleau, Heidi Grundtvig Theander, Karen Sørensen, Lone Abildgaard, and Majbritt Overgård, who obtained the data used in this paper during the Microbial Ecology course from the Department of Microbiology in 1999 under my supervision. This paper was partly based on their reports. The author was supported by a grant from the Brazilian agency CAPEs for his Ph.D studies in Denmark.

\section{REFERENCES}

BELSER, L. W. \& MAY. E. L., 1980, Specific inhibition of nitrite oxidation by chlorate and its use in assessing nitrification in soils and sediments. Appl. Environm. Microb., 39(3): 505-510.

BICHEL-COMMITTEE, T., 1999, Rapport fra underudvalget om: Miljø og Sundhed. Bichel-Udvalget, The Danish Ministry of Environment and Energy: 24-30 (Danish).

BRIX, H., 1998, Limnologi Øvelsesoversigt. Afdelinge for botanisk økologi. Biologisk institut. Århus Universitet.

CHEN S. K. \& EDWARDS, C. A. M., 2001, A microcosm approach to assess the effects of fungicides on soil ecological processes and plant growth: comparisons of two soil types. Soil Biol. \& Biochem., 33(14): 1981-1991.

CHEN S. K., EDWARDS, C. A. M. \& SUBLER, S., 2001, Effects of the fungicides benomyl, captan and chlorothalonil on soil microbial activity and nitrogen dynamics in laboratory incubations. Soil Biol. \& Biochem., 33(14): 1971-1980.
DAS, D. K., 1997, Nutrient transformation and yield of rice (Oryza sativa) as affected by soil application of insecticides in its flooded ecosystem. Indian Journal of Agricultural Ssciences, 67(8), 302-304.

FENCHEL, T., KING, G. M. \& BLACKBURN, T. H., 1998, Bacterial biogeochemistry: the ecophysiology of mineral cycling, $2^{\text {nd }}$ ed. Academic Press.

FRASER, A. J., BURKOW, I. C., WOLKERS, H. \& MACKAY, D., 2002, Modeling biomagnification and metabolism of contaminants in harp seals of the Barents Sea. Environ. Toxic. Chem., 21(1): 55-61.

GOLTERMAN, H. L., CLYMO, R. S. \& OHNSTAD, M. A. M., 1978, Methods of physical and chemical analysis of fresh water. Blackwell Scientific Publishers, Oxford, 214p.

HANSSON, G. B., KLEMEDTSSON, L., STENSTRÖM, J. \& TORSTENSSON, L., 1991, Testing the influence of chemicals on soil autotrophic ammonium oxidation. Environ. Toxic. Wat. Qual., 6: 351-360.

LAURSEN, A. E. \& CARLTON, E. G., 1999, Responses to atrazine of respiration, nitrification, and denitrification in stream sediments measured with oxygen and nitrate microelectrodes. FEMS-Microb. Ecol., 29(3): 229-240.

LOPEZ, M. C. C., 2003, Determination of potentially bioaccumulating complex mixtures of organochlorine compounds in wastewater: a review. Environ. Intern., 28(8): 751-759.

MATSUMURA, F., 1985, Toxicology of Insecticides. $2^{\text {nd }}$ ed. Plenum Press NY.

MILLER, J. L., SARDO, M. A., THOMPSON, T. L. \& MILLER R. M., 1996, Effects of application solvents on heterotrophic and nitrifying populations in soil microcosms. Environ. Toxic. Chem., 16: 447-451.

PELL, M., STENBERG, B. \& TORSTENSSON, L., 1998, Potential denitrifacation and nitrification tests for evaluation of pesticide effects in soil. Ambio., 27(1): 24-28.

RANGASWAMY, V. \& VENKATESWARLU, K., 1993, Ammonification and nitrification in soils, and nitrogenfixation by Azospirillum sp. as influenced by Cypermethrin and Fenvalerate. Agric. Ecos. Environ., 45(3-4), 311-317.

TU, C. M., 1991, Effects of some technical and formulated insecticides on microbial activities in soil. J. Environ. Sci. Health, B., 26(5-6): 557-573.

TU, C. M., 1994, Effects of some insecticides on microbial activities in sandy soil. J. Environ. Sci. Health, B., 29(2): 281-292.

TU, C. M., 1995, Effects of insecticides on microbial and enzymatic activities in sandy soil. J. Environ. Sci. Health, B., 30(3): 289-306.

TU, C. M., 1996, Effect of selected Herbicides on Activities of Microorganisms in Soils. J. Environ. Sci. Health, B 31(6): 1201-1214.

VINK, K. \& VAN STRAALEN, N. M., 1999, Effects of Benomyl and Diazinon on isopod-mediated leaf litter decomposition in microcosms. Pedobiologia, 43(4): 345-359.

WONK, J. W., 1991, Testing of pesticides for side-effects on Nitrogen conversion in Soils. Toxic. Environ. Chem., 30: 241-248. 